\title{
"İhtiyaç" Kavramı Ekseninde Sosyal Koruma: Temel İhtiyaçlar Yaklaşımı
}

\author{
DOĞA BAŞAR SARIIPEK* \\ sariipek@kocaeli.edu.tr
}

\begin{abstract}
Özet: İhtiyaç, somutlaştırılması ve tanımlanması güç bir kavramdır. Bu bağlamda, ihtiyaçların hangi ölçütlere göre belirleneceği, temel ve ileri ihtiyaçların neler olduğu, ihtiyaç içinde olanlarla olmayanların neye göre ve nasıl kesin olarak ayrılacağı gibi sorular sosyal refah ve koruma politikaları tasarlanırken sürekli sorulan ve tartışılan sorulardır. İhtiyaç temelli yaklaşım bu sorulara cevap olarak geliştirilmiş bir sosyal koruma yaklaşımıdır. Ancak genel anlamda ihtiyaç kavramının özünde bulunan sübjektif nitelikler ve içerdiği belirsizlikler nedeniyle, uygulaması kolay bir yöntem değildir. Bu nedenle, uygulamada herkesi kapsayabilmek adına "temel ihtiyaçlar" şeklinde bir daraltmaya gidilmiştir. Temel ihtiyaçlar yaklaşımının amacı, bireyin tam gelişimi için gereken firsatları sağlamak ve bu amaçla belli gruplar için belli kaynakları tahsis etmektir. Temel ihtiyaçlar yaklaşımının özü, gerçek yaşam düzeyiyle ihtiyaçlar arasındaki boşluğun diğer alternatif yaklaşımlara göre çok daha kısa sürede ve mümkün olan en az miktarda kaynak kullanılarak doldurulmasıdır. Ancak bu yaklaşım, teoriden kaynaklanan ciddi eksiklikleri nedeniyle hak temelli yaklaşımın sağladiğı sosyal koruma güvence düzeyini sağlamaktan uzak görünmektedir.
\end{abstract}

Anahtar kelimeler: İhtiyaç, Temel ihtiyaç, Sosyal koruma, Sosyal politika.

\section{Giriş}

İhtiyaç temelli yaklaşım, hayırseverlik/yardımseverlik ve hak temelli yaklaşımlarla birlikte sosyal kalkınmaya ilişkin sorunların çözümü için geliştirilen üç temel yaklaşımdan biridir. Bu üç yaklaşım, bireylere sosyal koruma sağlama performansları açısından sürekli kıyaslanmakta ve birbirlerine göre üstün ve zayıf yanları ortaya koyulmaya çalışılmaktadır.

Hayırseverlik/yardımseverlik temelli yaklaşım, en duygusal ve en içten gelen model olarak bilinmektedir. İnsanlar, yoksul ya da muhtaç durumda birini gördüklerinde ona para vermek ya da yardımcı olacak bir davranışta bulunmak ister. Aynı zamanda "cömertlik modeli" olarak da adlandırılan ve binlerce yıl boyunca sosyal sorunlarla mücadeledeki en önemli ve tek model olan hayırseverlik/yardımseverlik temelli yaklaşım, hayırseverin yoksulların ihtiyaçlarını bildiği ve cömertliği sayesinde bu ihtiyaçları karşıladığı varsayımına dayanmaktadır.

\footnotetext{
* Yrd. Doç. Dr., Kocaeli Üniversitesi, İIBF, Çalışma Ekonomisi ve Endüstri İlişkileri Bölümü. 
Asıl olarak acil ve anlık sıkıntıları ve ihtiyaçları gidermek üzere para, gıda, giysi, barınma desteği ve tıbbi bakım bağışları gibi yardımları içeren bu yaklaşımın en fazla eleştirilen tarafı, yoksulluk ve muhtaçlık halini kesin olarak ortadan kaldırmaması ve yardım alanları bağışlara daha da bağımlı hale getirmesidir. Ayrıca, birçok durumda yoksullar gerçek ihtiyaçlarını belirleme sürecine doğrudan dahil edilmediği için yaşamlarını hayırseverin istediği ya da beklediği biçimde değiştirmek zorunda hissedebilmektedir. Sonuç olarak, bu model sorunların nedenlerini ortadan kaldırmaya yönelik sistematik değişiklik anlamında hiçbir şey yapmamaktadır.

Hak temelli yaklaşım ise doğrudan doğruya insan hakları üzerine inşa edilmiş ve esas olarak insana yaraşır ve saygın bir yaşam sürmenin yasal ve bağlayıcı temellerinin atılmasını amaçlayan bir yaklaşımdır. Yasaların kesin bağlayıcılı̆̆ını içermektedir ve bireyin sosyal koruması devlete ait bir yükümlülüktür. Yani, birey hayırseverlerin insafına terk edilmemiştir ve en önemlisi, doğrudan sosyal koruma talep etme hakkı vardır.

Öte yandan, ihtiyaç temelli yaklaşım ise yaklaşık olarak XX. yüzyılın son çeyreğinden itibaren kalkınma yazınına girmeye başlamıştır. Bu yaklaşım, yoksulların bizzat kendileri tarafından belirtilen ihtiyaçlara yapılacak müdahalelerin temelini teşkil etmiştir. Bu anlamda çok önemli bir değişikliği de beraberinde getirmiştir. Bağışçılar artık yoksulların neye ihtiyaçları olduğuna keyfi biçimde kendileri karar vermemekte, bunun yerine yoksullar gerçek ihtiyaçlarının belirlenmesine ve bu ihtiyaçların hangi araçlarla giderileceğine ilişkin karar süreçlerine doğrudan katılmaktadır. Bu yaklaşım, hayırseverlerle muhtaçlar arasında saygın bir iletişim kurduğu için özellikle de hayırseverlik modeline göre ciddi bir gelişme ve ilerleme anlamına gelmiş ve esas olarak bu yönüyle desteklenmiştir.

İhtiyaç temelli sosyal kalkınma yaklaşımının üstün ve zayıf yanlarını belirterek, bu modelin sosyal kalkınma açısından etkili olup olmadığını ortaya koymaya çalışan bu çalışma, son derece geniş ve kapsamlı bir alan olan beşeri ve temel ihtiyaçlar tartışmasının tamamı üzerinde değerlendirmeler yapmak yerine, ihtiyaç, sosyal koruma ve refah kavramlarının kesiştiği noktaları açığa çıkarmayı hedeflemektedir. Çalışma üç ana bölümden oluşmaktadır. İlk bölümde ihtiyaç kavramının teorik temelleri tartışılmış ve sosyal koruma sistemlerinin tasarlanması ve uygulanması açısından önemi değerlendirilmiştir. Daha sonra, ihtiyaç kavramının “temel ihtiyaçlar” ekseninde daraltılarak sosyal politika ve sosyal koruma alanına uyarlanmaya çalışıld1ğ1 vurgusu yapılarak, sosyal kalkınmada ihtiyaç temelli yaklaşım detaylı bir şekilde açıklanmıştır. Son kısımda ise temel ihtiyaçlara dayalı sosyal kalkınma yaklaşımının üstün ve eksik tarafları bir arada değerlendirilerek, etkili bir sosyal koruma mekanizması olup olamayacağı tartışılmıştır.

\section{İhtiyaç Kavramına İlişkin Teorik Arka Plan}

İhtiyaç, somutlaştırılması ve tanımlanması güç bir kavramdır. Bu nedenle, birçok kaynakta farklı tanımlarına rastlanmaktadır. Kavramın tanımlanmasındaki bu çeşitlilik iktisat, sosyoloji, siyaset, psikoloji, hatta felsefe gibi birçok alanın ve disiplinin 
farklı bakış açılarının bir sonucudur. Örneğin, iktisadi bakış açısı ihtiyaç olgusunu tanımlarken bir genelleme yapmayı tercih etmekte ve "genel anlamda ihtiyaçlar" ve "temel ihtiyaçlar" ayrımını görmezden gelmektedir. ${ }^{1}$ Ana akım iktisat biliminin, ihtiyaç kavramının teorik alt yapısını geliştirmekten muhtemelen teoriler ve tartışmalar arasındaki ayrımın güçlügünden ve kavramın muğlaklığından dolayı kaçındığı ileri sürülmektedir. ${ }^{2}$

Sosyolojik bakış açısı ise tam tersine ihtiyaç kavramını ikili bir ayrıma gitmek suretiyle daha detaylı tanımlamayı tercih etmektedir. İlk olarak, ihtiyaç bireyleri motive eden bir faktördür. İhtiyaca yönelik ikinci sosyolojik açıklama ise ihtiyacı işlevsel bir ön şart olarak görmektedir. ${ }^{3}$ Yani, ihtiyaç bir başka durumu mümkün kılan ya da ona götüren süreçte uygulanması gereken bir durum ya da faktördür.

Psikolojik bakış açısı da benzer şekilde iki farklı anlam ve bunlara ilişkin bazı alt anlamlar içermektedir. Birinci anlama göre, ihtiyaç karşılanması halinde bir organizmanın iyilik ve refah düzeyini geliştirecek durumlar ve ilişkiler halidir. İkinci anlama göre ise ihtiyaç, bir organizmanın belli bir durum ya da ilişki gereksinimi içinde olduğu içsel bir durumdur. Bu anlam, ilkinden farklı olarak belli bir eksikliği ya da boşluğu giderecek bir çareye ilişkindir. Psikolojik bakış açısına göre, ihtiyaç olgusu bu iki temel anlamın haricinde bazı alt anlamlar da içermektedir. Bunlardan ilkine göre, ihtiyaç bir dürtüdür. Diğer bir alt anlama göre ise ihtiyaç bir güdü veya teşvik, arzu, tutku veya ihtirastır. ${ }^{4}$

İhtiyaç olgusunun muhtemelen en sık kullanılan ve en yaygın karşılaşılan anlamı siyaset bilimine göre yapılan tanımlamaya dayanmaktadır. Buna göre, ihtiyacın kendisi bağımsız bir kavram veya durum olmak yerine, daha çok başka kavram ve durumlar için bir araçtır. ${ }^{5}$ Buna göre, ihtiyaç belli bir eylemde bulunmak ya da belli bir duruma geçmek üzere yapılması gerekenlerin tamamıdır. Burada biraz daha farklı olarak kavramın detaylarına da inilmiştir. Örneğin beşeri ihtiyaç, bireyin zarar görmesinden kaçınmak için tatmin edilmesi gereken şartları ifade etmektedir.

İhtiyaç olgusunun en geniş anlama sahip olarak tanımlandığı durum, felsefi bakış açısına göre yapılan tanımlamadır. Buna göre, ihtiyaç bir organizmanın kendi türünün normal yaşamını sürdürmek için gerek duyduğu her şeydir. ${ }^{6}$ Buradaki normal yaşam ifadesiyle kastedilen, basitçe hayatta kalmaktan çok, gelişim ve ilerleme göstermektir. Bu durumda, bir ihtiyacın veya bir ihtiyaç tatmininin eksikliği, bir zarara yol açacaktır. Ancak tanımlamada bireyler ya da insanlar demek yerine, organiz-

1 Graham Bannock, Ron Eric Baxter ve Evan Davis, The Penguin Dictionary of Economics 5th Edition, London, UK, Penguin Books, 1992, s.262.

2 Tim Jackson, Wander Jager and Sigrid Stagl, "Beyond Insatiability: Needs Theory, Consumption and Sustainability”, Consumption: Perspectives from Ecological Economics. Edt: Reisch, L. ve I. Røpke, Cheltenham: Edward Elgar, 2004, s.3.

3 Nicholas Abercrombie, Stephen Hill ve Bryan S. Turner, The Penguin Dictionary of Sociology, London, UK, Penguin Books, 1994, s.343.

4 Arthur Reber, The Penguin Dictionary of Psychology, London, UK, Penguin Books, 3rd Edition, 1994, s.288.

5 Iain McLean ve Alistair McMillan, The Concise Oxford Dictionary of Politics, Oxford University Press, 2nd Edition, 2003, s.315.

6 Ted Honderich, The Oxford Companion to Philosophy, Oxford University Press, 2nd Edition, s.643. 
malar denmiştir. Bu da gelişim ve ilerleme göstermenin insanların ahlaki evreninde normatif bir önem taşıdığına ilişkin her türlü ön varsayımı zayıflatmaktadır.

Tüm bu çeşitlilik karşısında ihtiyaç, oldukça soyut bir kavram olarak karşımıza çıkmakta ve günlük hayatta bazı yakın anlamlı kavramlarla da karıştırılabilmektedir. İhtiyaçla en fazla karıştırılan kavramların başında tercihler, istekler ve ilgiler gelmektedir. İktisadi analizlerde sıkça kullanılan bir kavram olan tercihler, genellikle bir müşteri olarak mal ve hizmet satın alırken yaptığımız seçimler esnasında açığa çıkmakta ve bu özellikleriyle hem ihtiyaçlardan hem de isteklerden ayrılmaktadır. Bu durumda istekler de arzu edilen veya faydalı görülen, ancak temel ya da zorunlu olmayan her türlü duruma ilişkin kavramlar olarak tanımlanabilmektedir. İlgiler ise bireyin belli bir duruma dair sahip olduğu merak ya da kaygılar olarak tanımlanmaktadir.

Birbirine karıştırılması son derece yüksek bir ihtimal olan isteklerle ihtiyaçlar arasında bazı temel farklar bulunmaktadır. Bunlardan ilki, isteklerin çok daha kapsamlı ve geniş olmasıdır. Bu anlamda, aslında ihtiyaç olmayan şeylere de istek duyulabilmektedir. Ürün pazarlaması uzmanlarının olmasını istediği şey tam da budur. İkincisi, görmezden geldiğimiz ya da basitçe hoşlanmadığımız için aslında istemediğimiz şeylere de ihtiyaç duyabiliriz. Bunun en tipik örneği, tıbbi müdahalelerdir. Buradan hareketle, ihtiyaçların isteklere göre çok daha temel ve önemli oldukları ileri sürülebilmektedir. $^{7}$

İhtiyaçlarla istekler arasındaki bir başka ayrıma göre, isteklerin karşılanması "talep" şeklinde dile getirildikleri piyasaya bırakılmışken, ihtiyaçların karşılanması ise "devlet müdahalesini” gerektirmekte ve bunu meşru kılmaktadır. Nitekim devlet, tüm ihtiyaçların eşit biçimde karşılanmasını güvence altına alabilecek tek aktördür. Devlete alternatif olabilecek diğer kurumlar olan piyasa, aile ve sivil toplum dayanışması son derece belirsizdir ve kapsam açısından da eşitsizdir. ${ }^{8} \mathrm{Bu}$ nedenle, ihtiyaçların karşılanması meselesi sosyal hizmetlerin ve refah devletiyle piyasa arasındaki sınırı belirleyen temel ilkelerin varlık sebebi olarak görülebilir.

$\mathrm{Bu}$ özelliğiyle ihtiyaç kavramı, sosyal politikanın birçok alanında sıkça kullanılan kavramlardan biridir. Hatta Birleşmiş Milletlerin Binyıl Kalkınma Hedeflerinde ve genel olarak insani yardımlarda son derece açık biçimde görüleceği üzere, uluslararası sosyal politika alanında da sıklıkla kullanılmaktadır. Sosyal politika ve refah tartışmalarındaki ihtiyaç dili, başta analizleri daha etkili ve gerçekçi yapmak ve araçsal rolleri ve etkileri ortaya koymak olmak üzere, birçok işlevsel gereksinime cevap teşkil etmiştir. ${ }^{9}$

7 Nick Manning, "Social Needs, Social Problems, and Social Welfare and Well-being", The Student's Companion to Social Policy, Fourth Edition, Edt: Pete Alcock, Margaret May, Sharon Wright, John Wiley \& Sons, 2012, s.21; McCaslin, N. L., ve Jovan P. Tibezinda, “Assessing Target Group Needs”, Improving Agricultural Extension: A Reference Manual, Edt: Swanson, B.E., R.P. Bentz, ve A.J. Sofranko, Food and Agriculture Organization of the United Nations, Rome, 1997, s.39.

8 Paul Wetherly, "Basic Needs and Social Policies", Critical Social Policy, SAGE London, Thousand Oaks, CA and New Delhi, Vol. 16, 1996, s.46.

9 Des Gasper, "Conceptualisng Human Needs and Wellbeing", Wellbeing in Developing Countries: New Approaches and Research Strategies, Edt: I. Gough ve J.A. MacGregor, Cambridge University Press, s.54. 
İhtiyaçların sosyal politikayla ilişkilendirilmesi genellikle sol ya da toplumcu görüşler aracılığıyla olmuştur. Buna göre, ihtiyaçlar bireylerin içinde yaşadığı toplumun geleneksel standartlarını paylaşma hakkına ve yeterliliğine veya katılımın önemine vurgu yapan, göreli bir çerçevede açılklanmaktadır. Bu değerlendirmede tüm toplumlar için ve her dönem geçerli olan tek bir ihtiyaç standardı bulunmamaktadır. Burada etkili olan unsurlar, toplumların gelişmişlik düzeyleri, zenginlikleri, kültürel yapı farklılıkları ve gelenekleridir. Diğer taraftan liberal ve sağ görüşler ise her koşulda üretimin devamlılığını ve piyasada bir emek arzı tıkanıklığı yaşanmamasını en önemli hedef olarak belirledikleri için bedensel bütünlüğü ve verimliliği güvenceye alacak asgari gereklilikler olarak, ihtiyaçları temel ya da sadece geçimlik düzeyde tanımlamaktadır. ${ }^{10}$ Ancak bu kez de temel ihtiyaçların neler olduğu ve nasıl ölçüleceği konusunda yeni bir tartışma konusu ortaya çıkmaktadır.

\section{Temel İhtiyaçlar ve Sosyal Koruma}

Temel ihtiyaçlar yaklaşımı, ihtiyaç olgusunu somutlaştırmadaki güçlüğe karşı başvurulan yöntemlerden biridir. Esas olarak sosyal politika bakış açısının ve devletin bireysel ve toplumsal ihtiyaçları karşılama görevinin bir sonucu olan bu yaklaşım da genel ihtiyaç olgusuna benzer bir belirsizlik içermektedir. Bu konuda referans alınan ilk kaynaklardan biri, 1834 tarihli İngiliz Yoksul Yasasıdır. Devlete toplumun en yoksul kesimlerine karşı çok temel düzeyde sorumluluklar yükleyen bu yasayla sadece barınma, yiyecek ve son derece sınırlı bir sağlık hizmeti paketi temel ihtiyaçlar olarak belirlenip, kapsama alınmıştır. ${ }^{11}$ Günümüze yaklaştıkça, temel ihtiyaçlar fikrine önderlik eden başka teorik gelişmeler de yaşanmıştır. Bu kapsamda, 1940’lı yıllardaki psikoloji yazını, özellikle de Maslow'un 1942 yılında yazdığı ve beş ihtiyaç kategorisi tanımladığı makale temel ihtiyaçlar tartışmasına büyük katkı sağlamıştır. 1950'li yıllara gelindiğinde, bu kez Hindistan'da Pitambar Pant tarafından "asgari ihtiyaçlar” kavramı geliştirilmiş ve kavramın teorik çeşitliliği artmıştır. ${ }^{12}$

Temel ihtiyaçlar yaklaşımı söz konusu erken dönem boyunca, "hayatta kalmaya yetecek kadar olmak” şeklindeki ölçünün bir yansıması olarak değerlendirilmiştir. Ancak bu yaklaşımın bazı sorunları bulunmaktadır. Örneğin, komaya girmiş ya da kıtlık yaşamış ve aşırı derecede yetersiz beslenmiş bireyler hayattadır, ancak temel ihtiyaçlarının çoğunu ya hiç karşılayamamakta ya da zar zor karşılayabilmektedir.

Bu gibi eksiklikler dikkate alınarak, daha sonraki çalışmalarda temel ihtiyaçları belirlemek için "fiziksel sağlık durumu” ölçütünün daha başarılı olacağı ileri sürülmüştür. Çünkü günlük hayatta bir dizi eylemin yerine getirilebilmesi, ancak fiziksel sağlığın buna imkan vermesi halinde mümkündür ve bu da bedensel, fiziksel ve duygusal bazı yetilerin düzgün çalışıyor olmasını gerektirmektedir. ${ }^{13}$

Temel ihtiyaçların neler olduğu konusunda fiziksel sağlık ölçütü, hayatta kalma ölçütüne göre daha başarılı sonuçlar vermekle birlikte, bunun da bazı eksik tarafları

10 Cliff Alcock, Sarah Payne ve Michael Sullivan, Introducing Social Policy, Prentice Hall, UK, 2000, s.95. 11 Ken Blakemore ve Edwin Griggs, Social Policy: An Introduction, McGraw-Hill Education, 2007, s.27. 12 Louis Emmerij, "The Basic Needs Development Strategy", Background Paper World Economic and Social Survey, 2010, s.1.

13 Len Doyal ve Ian Gough, A Theory of Human Needs, Basingstoke: Macmillan Education, 1991, s.56. 
vardır. Nitekim bu yaklaşımda insanların ihtiyaçlarını karşılayabilmek için ne kadar sağlıklı olmaları gerektiği sorusunun cevabı yoktur. O nedenle, tüm bu değerlendirmeler ışığında, yokluğu ciddi zararlara neden olacak ihtiyaçlar, temel ihtiyaçlar olarak kabul edilmektedir. ${ }^{14}$

Temel ihtiyaçlara yönelik başka kavramsallaştırma çabaları da bulunmaktadır. Daha genel bir bakış açısı oluşturmaya çalışan bu yaklaşımlara göre temel ihtiyaçlar esas olarak, insanların saygın bir yaşam sürdürebilmek için gereken temel ve asgari maddi ihtiyaçlar ile gıda, barınma, sağlık hizmetleri, eğitim gibi mal ve hizmetler bütününe vurgu yapmaktadır. Buradaki temel varsayım, maddi gelirin insanlara saygın bir yaşam sürmelerini mümkün kılacak temel mal ve hizmetleri seçme imkanı vereceğidir. ${ }^{15}$

Temel ihtiyaçların neler olduğu konusu birçok düşünürün de ilgisini çekmiş ve bu konuda farklı görüşler ileri sürülmüştür. Örneğin Henry Shue temel ihtiyaçlarla temel haklar arasında doğrudan bir ilişki kurmuş ve ihtiyaç kavramını bu şekilde yorumlamıştır. Shue'ya göre, "temel haklar en azından bazı temel ihtiyaçların karşılanamaması tehdidine yönelik belirlenmiş toplumsal güvencelerdir" ve "haklar ancak başka hakların kullanılması onlara bağlı olduğunda temel hak niteliğine sahip olmaktadır". Temel haklar aynı zamanda, kimsenin daha azına sahip olmasına izin verilmeyecek bir eşik de oluşturmaktadır. Temel haklarla temel ihtiyaçları bu şekilde bir arada kurgulayarak Shue, 3 tür temel hak kategorisi öngörmüştür. Bunlardan ilki, fiziksel güvence ihtiyacına ilişkin güvenlik haklarıdır. İkincisi, asgari ekonomik güvence veya saygın ve normal bir yaşam sürdürebilme ihtiyacını karşılama imkanı sunan gıda, barınma, asgari sağlık hizmetleriyle ilişkili geçim haklarıdır. Son olarak, katılım ve dolaşım özgürlügü ihtiyacı gibi belli özgürlüklerle ilişkili haklar da bulunmaktadır. ${ }^{16}$ Dikkat edilirse tüm bu temel hak çeşitleri aslında asgari ve temel düzeydeki belli ihtiyaçlara dayandırılmıştır.

İhtiyaç olgusu hangi şekilde açıklanırsa açıklansın, kesin olan bir tarafı birbiriyle ilişkili, hatta çoğu zaman iç içe geçmiş toplumsal ve bireysel temellerinin bulunuyor olmasıdır. Çünkü ihtiyaç her zaman devlet refahı, sosyal adalet stratejileri, piyasa refahı ve Marksizm gibi tüm toplumcu tartışmaların ve stratejilerin merkezinde yer almıştır. Temel bir toplumcu değer olarak ihtiyaç kavramı, sosyal adalet fikriyle doğrudan bağlantılıdır. Nitekim genel toplumcu görüşe göre, serbest piyasa düzeninde yaratılan mal ve hizmetler ile yine piyasa tarafından gerçekleştirilen gelirin ve servetin dağılımı sosyal adaleti güvence altına almamaktadır. Çünkü tüm bireylerin "ihtiyaçlarının eşit düzeyde karşılanması” şeklindeki evrensel toplumcu ilkeyi sağlayamamaktadır. ${ }^{17}$ Dolayısıyla, ihtiyaçlar söz konusu olduğunda devletin mutlaka düzenleyici, müdahaleci ve yeniden dağıtıcı olması, yani "refah devleti” niteliğini taşıması gerektiği iddiası, bu tartışmanın bir sonucudur.

14 Blakemore ve Griggs, Social Policy, s.28.

15 Frances Stewart, "Human Development as an Alternative Development Paradigm", http://hdr.undp.org/docs/ training/oxford/presentations/2004/topic_1.

16 Henry Shue, Basic Rights, Subsistence, Affluence, and U.S. Foreign Policy, Second Edition, Princeton University Press, USA, 1996, ss.19-82.

17 Raymond Plant, “Socialism, Markets, and End States", Market Socialism, Oxford, 1989, s.54. 
Ancak insanların ne istediklerinin veya neye ihtiyaç duyduklarının, onlar bunu bir şekilde belli etmedikleri sürece, bilinmesi mümkün değildir. Bu nedenle, ihtiyaçların neler olduğuna kimin karar vereceği sorusu, sosyal politikada en fazla tartışılan konulardan biridir. Fabyanizm gibi kimi görüşler, ihtiyaçların bilimsel olarak tanımlanmasına ve uzman görüşlerine büyük önem atfetmektedir. Bu durumda, refah hizmetleri önceden tanımlanmış bu ihtiyaçlara göre tasarlanıp uygulanacaktır. Ancak bu ihtiyaç analizi ve tanımlaması süreci başarılı bir sistematik içinde yapılmadığında yoksul bireylerin ihtiyaç önceliklerini doğru anlamak ve bunlara en uygun karşılı̆̆ı vermek mümkün olmayabilmektedir. ${ }^{18}$

Ayrıca, bu yaklaşımın yani beşeri ihtiyaçların ihtiyaç sahipleri yerine başkaları tarafından yukarıdan belirlenmesinin demokratik olmadığı, bu yolla sadece gözlenebilen ihtiyaçların dikkate alınabileceği ve insanların duygusal ihtiyaçlarının dikkate alınamayacağı gibi eleştiriler de ileri sürülmektedir. Bu eleştirilerin bir sonucu olarak, bireylerin ve toplumların kendi ihtiyaç algılarının ve tanımlamalarının önemine vurgu yapan karşı bir görüş ortaya çıkmıştır. ${ }^{19}$ Yani, her yerde ve her zaman geçerli evrensel bir standart savunmak yerine, kişiye, gruplara, bölgeye ve zamana göre değişen ihtiyaçların olabileceği, sunulacak refah hizmetlerinin de bu nedenle, dinamik ve esnek bir yapıya sahip olması gerektiği savunulmaktadır.

Ne var ki, bireylerin ihtiyaçlarını ve diğer taleplerini dile getirmesinin görünen ve görünmeyen bazı sınırları vardır. Örneğin istekler piyasada ancak yeterli para olduğunda ifade edilebilmektedir. Benzer şekilde ihtiyaçlar da bireyler onların varl1ğından haberdar değilse veya söz konusu ihtiyaçları karşılayacak hizmetler bulunmuyorsa birey tarafından fark edilememekte ve açıklanamamaktadır. Bu durumda, ihtiyaçların bireyin kendisi dışındaki bir takım ilgili kişiler tarafından görülmesi ve bunları gidermek üzere harekete geçilmesi bir zorunluluk halini almaktadır. ${ }^{20}$

İhtiyaçların bireysel ya da toplumsal olarak saptanmasının güçlüğü, çoğu zaman her iki durumun birbiriyle iç içe geçmiş olmasından kaynaklanmaktadır. Daha açık bir ifadeyle, bir ihtiyacın tamamen bireysel bir ihtiyaç olarak görülebilmesi ve toplumun geri kalanından ayrıştırılması için bazı şartların gerçekleşmesi gerekmektedir. Nitekim bireysel ihtiyaçlar, ancak kişisel nedenlerle ve hastalık, yoksulluk gibi olumsuz tecrübelerle ilişkili olmadığında toplumsal bir niteliğe bürünmektedir. Ayrıca, benzer yaşam koşullarını paylaşmaları nedeniyle bu hastalıkların ve yoksulluk olgusunun o grubun tamamını ya da büyük bir kısmını etkilemesi de gerekmektedir. Örneğin, bulaşıcı bir hastalığın yayılmasının önüne geçmek için yaygın aşı kampanyası başlatılması toplumsal bir ihtiyaçtır. Böyle bir durumda, nüfusun tamamının bir ihtiyacı vardır, ancak tek bir birey bunu tek başına açıkça hissedemeyebilmektedir. ${ }^{21}$ Toplumsal ihtiyaçlar en çok sosyal refah kurumları ve uygulamaları organize edilirken önem kazanmaktadır. Çünkü sosyal refah politikalarının en temel hedefi toplumsal ihtiyaçların en başarılı şekilde karşılanmasını sağlamaktır.

18 Needs Based Development (Yazar Yok), http://www.repository.up.ac.za/bitstream/ handle/2263/28771/03chapters7-10.pdf? sequence $=4$.

19 Alcock C. vd., Introducing Social Policy, s.95.

20 McCaslin, ve Tibezinda, “Assessing Target Group Needs", s.39; Manning, “Social Needs", s.21.

21 Doyal ve Gough, A Theory of Human Needs, s.57. 
Ancak toplumsal ihtiyaçların ve sorunların bilimsel ve nesnel ölçütlerle tanımlanmasının mümkün olup olmadığı konusunda yoğun bir tartışma bulunmaktadır. Bunun mümkün olmadığını savunan görüşe göre, ihtiyaçlar ve sorunlar ancak öznel toplumsal koşullara göre tanımlanabilmekte ve tanımı yapacak kişinin kendine özgü ilgi ve çıkarları tarafından şekillenmektedir.

Bu noktada da hangi ihtiyaçların öncelikli olduğu tartışması önemlidir. Daha açık bir ifadeyle, toplum düzeninin ve toplumun genel faydasının bireysel faydadan daha öncelikli olduğu salt çoğunlukçu bir bakış açısıyla ileri sürülebilir. Buna göre, sonuç itibariyle daha fazla kişinin faydasına olacak bir durum için, daha az sayıdaki bireysel zararlar ya da bazı bireysel ihtiyaçların karşılanamaması durumu bir yere kadar hoşgörülebilmektedir. Ancak sosyal refah politikalarının nihai hedefinin mutlaka toplumun tamamının faydasına olacak kararlar alıp uygulamak olması şarttır. Eğer haklar, ihtiyaçlar ve bireyler arasında bir öncelik-sonralık ayrımı yapılırsa, son derece öznel, hatta klientalist uygulamalar yaşanabilmekte ve sosyal refah politikaları da bir dönemden diğerine sürekli değişen, sistematiklikten ve kurallara bağlı olmaktan uzak, etkisi de kısıtlı programlara dönüşebilmektedir.

\section{İhtiyaç Olgusunun Sosyal Politikadaki Yeri}

İhtiyaç denildiğinde tek tip ve evrensel bir kavramdan bahsedilmemektedir. Nitekim farklı ihtiyaç türlerini gösteren birçok sınıflandırma bulunmaktadır ve bunlar ihtiyaç kavramına farklı pencerelerden yaklaşmaktadır. Bu kapsamda, ihtiyaçların sosyal politikadaki yerine ve önemine ilişkin en bilinen sınıflandırmalardan biri Jonathan Bradshaw (1972) tarafından geliştirilmiştir. Bradshaw, ihtiyaçları hissedilen, ifade edilmiş, normatif ve kıyaslamalı ihtiyaçlar olmak üzere 4 gruba ayırmıştır. ${ }^{22}$

Hissedilen İhtiyaçlar: Bireyler bu tür ihtiyaçlarının tamamen bilincindedirler. Yani kesin bir farkındalık vardır. Bunlar, örneğin birey hastalandığında ya da bir kaza geçirdiğinde çok net bir biçimde ortaya çıkmaktadır. Ancak hissedilen ihtiyaçlar her zaman dile getirilmeyebilirler. Bunun nedeni kişinin ihtiyacını ifade etmeyi tercih etmemesi olabileceği gibi, toplumda var olan güç ve statü dengesizliklerine bağlı olarak, güçsüz veya baskı altında kalmış olmaktan da kaynaklanabilir. ${ }^{23}$

Bu tür ihtiyaçlar, isteklerle aynıdır. Refah sağlayıcı kurumlar, ihtiyacı bir refah hizmeti tasarlamak veya uygulamak için değerlendirirken, bireylere o hizmete ihtiyaçları olduğunu hissedip hissetmedikleri sorulur. Bu nedenle, hissedilen bireysel ihtiyacın, demokrasilerde toplumsal ihtiyacın önemli bir bileşeni olduğu düşünülebilir. Ancak hissedilen ihtiyaç, bireyin algısıyla sınırlanmış olduğundan, tek başına gerçek ihtiyaç analizi için yetersiz bir ölçüdür. Ayrıca, gerçekten ihtiyaç sahibi olmadığı halde yardım isteyenler tarafından abartılacağı ve suiistimal edileceği de genelde kabul edilmektedir. ${ }^{24}$

22 Jonathan Bradshaw, "A Taxonomy of Social Need", Problems and Progress in Medical Care, Edt: McLachlan G., Seventh Series NPHT/Open University Press, 1972, s.77.

23 Blakemore ve Griggs, Social Policy, s.30; Manning, "Social Needs", s.21.

24 Amanda Smith Barusch, Foundations of Social Policy Social Justice in Human Perspective, the USA, Brooks/ Cole, 2009, s.3. 
Ífade Edilen İhtiyaçlar: Bu ihtiyaçlar dışarıya duyurulur ve etrafça bilinir. Bunlar, ihtiyacını açıklamaya isteksiz veya çok güçsüz olanların gizli ihtiyaçlarının aksine, artık talep haline gelmiş ihtiyaçlardır. ${ }^{25}$

İfade edilen ihtiyaçlar veya talepler, hissedilen ihtiyaçların eyleme dönüşmüş halidir. Dolayısıyla, ifade edilen ihtiyaçların toplamı, bir refah hizmeti talep edenlerin tamamının ortak bir ihtiyacı olarak tanımlanır. Yani, ifade edilen ihtiyaçların bir araya gelmesiyle, toplumsal ihtiyaca ulaşılacağı kabul edilir. Ancak bunun tersi durumlar da söz konusu olabilir. Nitekim bu durumda birey, ihtiyacı varmış hissetmediği sürece bir hizmet talep etmez. Diğer yandan, talep yoluyla dile getirmeme davranışı ifade edilen ihtiyaçlar için yaygın bir durumdur. Bunun en tipik örneği sağlık hizmetlerinde görülür. Burada bekleme listeleri, karşılanmamış ihtiyaçların bir ölçüsü olarak kabul edilir. Buna göre, bekleme listeleri genellikle gerçek ihtiyacın zayıf bir göstergesidir. ${ }^{26}$

Normatif İhtiyaçlar: Genellikle doktor ya da eğitimci gibi bir uzmanın, yöneticinin, sosyal bilimcinin ya da aile veya arkadaşların belli bir durum karşısında bizim için ihtiyaç olarak tanımladığı durumlardır. Burada, olması arzu edilen ideal bir standart belirlenir ve gerçekte var olan standartlarla kıyaslanır. Eğer bir grup ya da birey arzu edilen standardı karşılayamıyorsa, bu durumda bu birey ya da grup ihtiyaç sahibi olarak kabul edilir. Örneğin, devlet koruması altındaki çocukların yerleştirileceği bakıcı aile evlerinde bulunması gereken standartlar önceden belirlenmiştir. Uygun bakıcı aile bulmakla görevli sosyal hizmet görevlileri, hem bu standartlara hem de kendi mesleki tecrübelerine göre, evlerin çocukların ihtiyaçlarını karşılamaya uygun olup olmadığına karar vermek zorundadır. ${ }^{27}$

Normatif tanımlamayla ilgili bir sorun, farklı mesleki uzmanlar tarafından farklı dönemlerde birbiriyle çelişen standartların belirlenebilmesidir. Hatta siyasi, kültürel ve başka sebeplerle, sübjektif değer yargılarının burada belirleyici olması sık karşılaşılabilen bir durumdur.

Normatif ihtiyaçlar tartışması aslında refah tartışmalarına bir başlangıç niteliği taşımaktadır. Braybrooke normatif ihtiyaçlar tartışmasına siyasal ideoloji bakış açısını da katarak, aşağıdaki değerlendirmelerde bulunmuştur:

1. Hemen hemen tüm siyasal topluluklarda, belli bir hedef nüfus adına kararlar alan bir karar yapıcı üst sınıf veya grup vardır.

2. Bireyin bir ihtiyacı belirlemek üzere başvurduğu bir kıstas ya da amaç bulunmaktadır. Ayrıca, bu kıstasın gerektirdiği uygulamalardan türetilmiş bir ihtiyaçlar dizisi vardir.

3. Belli tatmin edicilerin veya doyuranların seçilen kıstasın gerçekleştirilmesine ne düzeyde katkı sağladığının belirlendiği bir "farklı düzeyler dizisi” söz konusudur.

25 Blakemore ve Griggs, Social Policy, s.30.

26 Barusch, Foundations of Social Policy, s.3.

27 Barusch, Foundations of Social Policy, s. 30; Manning, "Social Needs", s.21. 
4. Her bir ihtiyaç türü için geçerli olan her bir düzeyde belli bir gösterge ve özelleştirilmiş bir hedef bulunmaktadır. ${ }^{28}$

Düzeyler arasında araçsal ilişkiler ve bağlantılar da bulunabilmektedir. Daha açık bir ifadeyle, bir davranış, ürün ya da hizmet gibi faktörler birden çok ihtiyacın karşılanmasına katkı sağlayabilmekte veya bir ihtiyaç ya da boşluk genellikle birçok alternatif faktör tarafından karşılanabilmektedir. Ayrıca, önerilen her bir faktör etkili olmayabilmektedir. Yani, ihtiyacı karşılayacağı kesin değildir.

Kıyaslamalı İhtiyaçlar: Bu tür ihtiyaçlar kısmen ifade edilen ihtiyaçların bir uzantısıdır ve "göreceli karar" kavramına dayanarak ortaya çıkmaktadır. Bunun anlamı, bir grubun ihtiyaçlarının başka bir grubun sahip olduklarına ya da olmadıklarına göre tanımlanmasıdır. Yani, herhangi bir refah hizmeti alan bir grubun özellikleri incelenir ve buna göre sosyal politika açısından bir ihtiyaç eşiği elde edilir. Burada adalet kavramının bir yansıması da vardır. Eğer benzer koşullardaki iki gruptan sadece bir tanesi refah yardımı ya da desteği alıyorsa, refah hizmeti alamayan grup adaletsiz biçimde refahtan mahrum kalmıştır ve diğer gruba kıyasla ihtiyaç içindedir. Çünkü diğer grup içindekiler bireyin kendisinde olmayan bir şeye sahiptir. Kıyaslamalı ihtiyaç kavramı, hem bireylerin hem de bölgelerin ihtiyaçlarını değerlendirmek için kullanılmaktadır. ${ }^{29}$

\section{Refah Düzeyi ve İhtiyaçların Ölçülmesi Sorunu}

İhtiyaç kavramına ilişkin kafa karışıklığının bir benzeri refah alanında da söz konusudur. İnsanların isteklerini ve tercihlerini açıklamalarının merkezine alan ve hatta bazı durumlarda kabul edilebilir tek normatif kıstas olarak gören ana akım iktisat öğretileri, refah konusunun ampirik ve kavramsal arka planını daha detaylı araştırmayı çok uzun bir süre boyunca diğer disiplinlere bırakmıştır. ${ }^{30}$

Tıpkı ihtiyaç tartışmasında olduğu gibi, refah alanında da kavramsal olarak birçok değişkenden ve düzeyden bahsetmek mümkündür. Refaha ilişkin bilinen birçok kavram farklı düzeylere denk gelmektedir. Ancak ihtiyaç kavramından farklı olarak, refah çok daha normatif bir kavram olduğu için refah kavramlarının söz konusu düzeyleri arasındaki zıtlık çok daha az belirgindir. İhtiyaçların bireysel mi yoksa toplumsal olarak mı belirlenmesinin daha doğru olduğu tartışmasına benzer bir şekilde, refah alanında da "objektif refah" ve "sübjektif refah" şeklinde ikili bir tartışma bulunmaktadır. Objektif refah esas olarak bireyin kendisi dışında değerlendirilen ve onaylanan ve bu nedenle de yerinde ve uygun görülen bazı duygu dışı özellikleri içermekte ve ihtiyaçların toplumsal olarak saptanması tartışmasına paralellik göstermektedir. Bunun en temel örnekleri, seyahat ve dolaşım imkanları ile sağlık ve yaşam süresidir. Sübjektif refah ise tam tersine bireyin duygularını ve/veya kararlarını merkeze almakta ve ihtiyaçların bireyin kendisi tarafından saptanması tartışmasına benzemektedir. ${ }^{31}$

28 Gasper, “Conceptualising Human Needs”, ss.13-14.

29 Blakemore ve Griggs, Social Policy, s.30; Barusch, Foundations of Social Policy, s. 3; Manning, "Social Needs", s.21.

30 Gasper, “Conceptualising Human Needs”, s.14.

31 Peter Taylor-Gooby, "Equality, Rights, and Social Justice”, The Student's Companion to Social Policy, Fourth 
Filozof Derek Parfit (1984), objektif/sübjektif refah şeklindeki bu ikili ayrımı bir adım daha ileri taşımış ve refaha ilişkin üç bileşenli bir ayrım yapmıştır. İlk ayrım, hedonizmdir ve refahın bir haz ve zevk duyma haliyle bütünleştirilmiş olduğu bir aşamayı ifade etmektedir. İkinci ayrım, tutku teorilerine dayanmaktadır. Refah burada, tercihlerin ve tutkuların karşılanmasıyla eş anlamlı düşünülmektedir. Son ayrım, objektif liste teorileridir. Refah burada bir yaşamı iyi yaşanmış kılan tüm eylemleri içeren bir listeyi gerçekleştirmekle eş tutulmaktadır. ${ }^{32}$

Toplumsal ihtiyaçların nasıl tanımlanacağı ya da saptanacağı konusu refah hizmetlerinin karşılaştığı en ciddi sorunlardan biridir. Çünkü bir toplumda ihtiyaçların ne şekilde tanımlandığı ve görüldüğü konusu, bunları gidermek üzere hayata geçirilecek politik müdahalelerin saptanması açısından son derece önemlidir. Bu tartışma, genellikle temel ihtiyaçlar kavramı üzerinden yürütülmektedir. Buna göre, bir tarafta temel ihtiyaçların "bireyin hayatta kalması için gereken her şey" veya "kişinin toplum içinde bağımsız bir birey olarak yer almasını mümkün kılan ihtiyaçlar” gibi somut ve objektif bir tanımlaması olması gerektiğini savunanlar bulunmaktadır. Diğer tarafta ise bireylerin kendileri, uzmanlar ya da hükümet birimleri ile ihtiyaçların karşılanması için gereken hizmetleri tasarlayan diğer kuruluşlar gibi ihtiyaçların daha öznel tanımlanması gerektiğini savunanlar bulunmaktadır. ${ }^{33}$

$\mathrm{Bu}$ tartışmaların yaşandığı en somut sosyal sorun alanlarından biri yoksulluktur. Yoksul olduğu düşünülen bir bireyin ne kadar bir gelire ihtiyacı olduğu önemli bir sorudur. Çünkü sosyal koruma politikaları buna göre tasarlanacaktır. Bu soruya yönelik olarak geliştirilen bir yaklaşım, ihtiyaçları uzmanların tanımladığı normatif ihtiyaç sınıflandırmasına dayanmaktadır. Buna göre, ihtiyaçlar gıda, kıyafet, barınma gibi temel ihtiyaçlardır ve tüm bunların en ucuz ve asgari düzeyde tedarik edilmesi için gereken para miktarı, sosyal koruma sistemlerinin yoksullara sağlaması gereken doğru yardım miktarıdır. Ayrıca, söz konusu asgari para düzeyi kimin yoksul ya da muhtaç olduğu, kimin olmadığı sorusunun da cevabını veren bir eşik görevi de görmektedir. ${ }^{34}$

Ancak bu konuda yapılan çalışmalar, "temel ihtiyaç" ya da "en ucuz ve asgari tedarik" yaklaşımının ailelerin ve toplumun yaşam tarzına göre değişebileceğini göstermiştir. $\mathrm{Bu}$ anlamda örneğin, televizyon ya da internet kullanımı kimi aileler ya da toplumlar için temel bir ihtiyaç olarak sınıflandırılırken, diğerleri için temel ihtiyaç olarak görülmeyebilir. ${ }^{35}$

Alternatif bir yaklaşım, hissedilen ihtiyaç kavramını kullanmakta ve doğrudan yoksul bireylere neye ihtiyaç duyduklarını sormaktadır. Ancak, bu yaklaşımın uygulandığı yerlerde yoksul bireylerin genellikle kendi koşulları üzerinde ayarlamalar yaptıkları ve özellikle de yaşı bireyler olmaları halinde normalde olması gerekenden

Edition, Edt: Pete Alcock, Margaret May, Sharon Wright, John Wiley \& Sons, 2012, s.28.

32 Gasper, "Conceptualising Human Needs", s.15.

33 Manning, "Social Needs", s.22.

34 Robert M. Page, “The Post-War Welfare State”, The Student's Companion to Social Policy, Fourth Edition, Edt: Pete Alcock, Margaret May, Sharon Wright, John Wiley \& Sons, 2012, s.126.

35 Manning, "Social Needs", s.22. 
daha az ihtiyaç halinde hissettikleri ya da tam tersine, normalde yoksul olmadıkları halde yoksul hissettikleri anlaşılmaktadır. Son olarak, kıyaslamalı ihtiyaç durumunu esas alan yaklaşıma göre ise örneğin gelir düzeyi bakımından yakın çevresiyle kıyaslandığında ve bir sıralama yapıldığında en dipteki \%10'luk dilime girenler yoksul kabul edilmektedir. ${ }^{36}$

İhtiyaçların nasıl anlaşılacağı ya da şiddetinin nasıl ölçüleceği sorusu, özellikle feminist iktisatçılar açısından önemle üzerinde durulan bir konudur. Feminist görüş mensupları, diğer ana akım yaklaşımları ailenin içine bakmakta yetersiz oldukları için eleştirmektedir. ${ }^{37}$ Yani, onlara göre hane bireylerinin her birinin ayrı ayrı ihtiyaçları vardır ve bunların her birinin şiddeti de birbirinden farklıdır. Buna nedenle, genelde yapıldığı gibi, ihtiyaçların hanenin kaynaklarına bir bütün olarak bakılıp ölçülmesi, o hanede yaşayan herkesin bu kaynaklara eşit düzeyde erişimi olduğu gibi bir varsayıma dayanmaktadır. Ailenin tamamı bir bütün olarak ele alınıp, çok genel bir ihtiyaç tespiti yapıldığ 1 için, aileye verilecek sosyal koruma ve refah hizmetleri de buna göre belirlenir. Ancak feminist görüşe göre bu doğru bir yöntem değildir; kadınlar, çocuklar, yaşlılar ve yetişkin erkekler arasında kaynaklar eşit dağılmamış olabilir.

Kısaca özetlemek gerekirse, ihtiyaçlar konusu sosyal politika ve sosyal koruma tartışmalarının merkezinde yer almaktadır. Ama neredeyse tamamen soyut bir kavram olması nedeniyle, teorik çerçevesini çizme konusunda bile bir bütünlük ve yeknesaklık henüz sağlanabilmiş değildir. Bu bağlamda, örneğin bireyin kendi ihtiyaçlarını hangi düzeye kadar kendi başına karşılaması gerektiği, refah devleti kurumlarının ve politikalarının hangi aşamada devreye gireceği, temel ihtiyaçların neler olduğu ve bunların zamana, topluma, bireyin kişilik özelliklerine göre değişip değişmediği gibi soruların evrensel bir cevabı bulunmamaktadır. Ancak tüm bu belirsizliklere ve kavramın özünde bulunan soyutluğa rağmen, beşeri ve toplumsal ihtiyaçlara dayalı kalkınma plan ve programları ülkelerin sosyal kalkınma süreçlerinde önemli bir yer tutmaktadir.

\section{Temel İhtiyaçlara Dayalı Sosyal Kalkınma}

Kalkınma kavramına yönelik birçok farklı yaklaşım ve açıklama bulunmaktadır. Bir genelleme yapmak açısından, kalkınma olgusu neredeyse kaçınılmaz olarak hemen hemen tüm tanımlamalarda normatif bir kavram olarak görülmekte ve ilerlemeyle eş anlamlı kabul edilmektedir. Başka bir yaklaşıma göre ise kalkınma başka ülkelerin kalkınma çizgilerinin aynen kopyalanması ve mevcut durumlarının açık bir şekilde ulaşılmak istenen bir hedef olarak belirlenmesidir. ${ }^{38}$

Kalkınma olgusuna yönelik bakış açısı zaman içinde ciddi bir kavramsal değişim de geçirmiştir. Bu anlamda önemli bir kalkınma teorisyeni olan Seers, kalkınmanın amacının yoksulluğu, eşitsizliği ve işsizliği azaltmak olduğunu ileri sürmüştür.

36 Manning, "Social Needs", s.22.

37 Alcock vd. Introducing Social Policy, s.95.

38 Dudley Seers,『”'The Meaning of Development”,囚IDS Communication Series, No: 44, 1969, s.2. 
Seers’a göre, neoklasik iktisatçıların en büyük hatası, Batı deneyimlerini evrenselleştirme eğilimleridir. Bu durumda, birey mevcut doktrini ne kadar iyi özümserse, kendi toplumsal durumunu buna adapte etmesi o kadar zorlaşmaktadır ${ }^{39}$. Çünkü birey mevcut durumun mutlak etkisi altındadır ve bu etki kendi öz koşullarını genel ilkelere uyarlamasina engel olmaktadır.

Bunun yanı sıra, Seers büyüme hedefinin öncelikli ve tek hedef olarak belirlenmesine de aşağıdaki soruları sormak suretiyle karşı çıkmıştır:

"Yoksulluk, eşitsizlik ve işsizlik konusunda ne gibi çalışmalar yapılıyor? Eğer bu üç temel sorun alanı daha düşük ve nadir görülür hale gelirse, bu kesinlikle söz konusu ülke için bir kalkınma dönemi yaşandığının göstergesidir. Ancak eğer bu sorunlardan bir ya da ikisi daha da kötüleşirse, hatta üçünde birden bir kötüleşme yaşanırsa, kişi başına düşen gelir düzeyi yükselmiş olsa bile bu sonucu kalkınma olarak adlandırmak yanlış olacaktır. ${ }^{40 "}$

Sen ise daha farklı bir yaklaşımla kalkınmayı mahrumiyetlerin azaltılması ve tercihlerin genişletilmesi olarak açıklamıştır. Buradaki mahrumiyet durumu açlığı, okuryazar olmamayı, hastalıkları ve genel olarak kötü bir sağlığa sahip olmayı, güçsüzlüğü, sesini ve taleplerini duyuramamayı, güvencesizliği, aşağılanmayı ve temel altyapı hizmetlerine erişim eksikliğini içeren çok boyutlu bir yoksulluk anlayışına dayanmaktadır. ${ }^{41}$

Bu durumda, ekonomik yaşamın nihai hedefi ve yüksek bir refah düzeyine ulaşmanın en etkin aracı olarak kalkınma değil, özgürlük düzeyi önem kazanmaktadır. Nitekim mahrumiyetlerden kurtulmak da kalkınma yolunda kilit önemdeki bir unsurdur. Özgürlüğün bulunmaması açlık, kıtlık, ihmal, sürdürülemez bir ekonomik yaşam, işsizlik, kadınların veya azınlık topluluklarının ekonomik olarak kendilerini gerçekleştirmelerinin önünde engellerin bulunması, zamansız ve erken ölüm, siyasal özgürlüğün ve temel özgürlüklerin ihlali, çevre tehditleri ile sağlık hizmetlerine ve temiz suya erişimin kısıtlı olması gibi sorunlar ve mahrumiyetler içermektedir. Açıkça görüleceği gibi bu yaklaşım, ulaşılabilir bir yeterlilikler dizisinden hareketle, refah düzeyini doğrudan belirleyen az sayıdaki temel işlevselliklere odaklanmaktadır. Bu durumda da yaşam, bireyin "olma” ve "yapma” imkanlarına veya genel olarak bir işlevsellikler dizisine ulaşma şeklindeki etkin bir özgürlük halinden oluşmaktadır. ${ }^{42}$ Tüm bunların bir sonucu olarak, Sen’in refah teorisinin öz itibariyle bireylerin temel ihtiyaçlarına değil, yeterliliklerine dayanmakta olduğu açıkça görülmektedir.

Temel ihtiyaçlara dayalı kalkınma politikaları ise dünya siyasetinde genellikle dalgalı bir seyir izlemiş ve gücünü ve etkinliğini sürekli olarak koruyamamıştır. Bu yaklaşımın nihai amacı bireyin fiziksel, zihinsel ve toplumsal açılardan tam gelişiminin

39 Dudley Seers, “The Limitations of the Special Case”, Bulletin of the Oxford Institute of Economics and Statistics 25(2), 1963, s.77.

40 Seers, “The Meaning of Development”, s.3-4.

41 Wayne Nafziger, "From Seers to Sen: The Meaning of Economic Development", UN University/World Institute for Development Economics Research (WIDER) Jubilee Conference, 17-18 June 2005, s.1.

42 Amartya Sen, Development as Freedom, Alfred A. Knopf, New York, 1999, ss.15-25. 
sağlanmasıdır. Bu amacı gerçekleştirmenin en kısa yolu ise belli kaynaklara erişimi kısıtlı ya da yetersiz olan grupların söz konusu kaynaklara erişimlerinin bir şekilde mümkün kılınmasıdır. Ancak ihtiyaç temelli yaklaşımın tek amacı bu değildir. Etkin ve arzu edilen bir davranışı özendirmek üzere müdahalede bulunmak, kamu finansmanı ve harcamaları konusunda ve genel olarak toplumsal planlama alanında insanların farkındalığını arttırmak, söz konusu harcamaların meşruiyetini ve şeffaflığının sağlamak, toplumsal ihtiyaçların yanlış anlaşılmasını önlemek, sosyal koruma uzman ve yetkililerinin öncelikli müdahale alanlarını ve programlarını belirlemesine yardımcı olmak, sorunların doğru ve isabetli analiz edilmesini ve bunlara yönelik etkin çözüm yollarının saptanmasını sağlamak ve çift yönlü bir iletişim süreci kurmak ihtiyaç temelli yaklaşımın diğer başlıca amaçlarıdır. ${ }^{43}$

İhtiyaç temelli yaklaşımın temel öngörülerinden biri, bazı beşeri ihtiyaçların kesin olarak tanımlanabildiği ve hükümetlerin o toplumda geçerli bulunan kalkınma düzeyinin elverdiği ölçüde bu ihtiyaçları karşılama zorunluluğunun bulunduğudur. Bu durumda refah kaçınılmaz ve kesin bir hükümet görevi olarak önem kazanmakta ve temel ihtiyaçlar yaklaşımı da bu iddiaya ilişkin en sağlam temellerden birini oluşturmaktadır. ${ }^{44} \mathrm{Bu}$ amaç ve öngörüleri neticesinde, temel ihtiyaçlar yaklaşımı basit ve doğrudan gelir aktarımını içeren politika ve hizmetler dışındaki diğer hizmet ve sunumlarla daha çok ilgilenmektedir. Bu nedenle de "yoksulluğun ortadan kaldırılması" ve "işsizliğin azaltılması" şeklindeki geleneksel politikalara göre daha pozitif ve sağlam bir yaklaşım olduğu ileri sürülmektedir. ${ }^{45}$

Temel ihtiyaçlara dayalı kalkınma stratejisi, yaklaşık olarak 1970'li yılların ortalarında ILO’nun “Dünya İstihdam Programı” başlıklı çalışmasından doğmuştur. Bu çalışma, istihdamın yanı sıra, bireyleri ve beşeri ihtiyaçları kalkınma stratejilerinin merkezine yeniden yerleştirmiştir. İstihdam BM ve IMF gibi başka küresel örgütlerin de sürekli olarak gündemlerinde bulunmuştur. Ancak ILO’nun fark1, istihdam meselesini kalkınmakta olan ülkelerin ihtiyaçlarıyla ilişkilendirmiş olmasıdır. Bu yeni dönemde ayrıca, istihdam yaratmanın kendisinin bir sonuç olmadığı ve aslında bireylerin temel ihtiyaçlarını karşılamalarına hizmet ettiği açık olarak anlaşılmıştır. $\mathrm{Bu}$ da hemen hemen Maslow'un beş aşamalı ihtiyaçlar hiyerarşisinin ilk basamağına denk gelmektedir. Birçok birey şimdiden ikinci, üçüncü, dördüncü ve hatta beşinci basamakta olmakla birlikte, nüfusun büyük bir bölümü henüz ilk basamağın yak1nında bile değildir. Bu nedenle, nüfusun en yoksul \%20'lik kısmını kapsayan ve esas amacı temel ihtiyaçları karşılamak olan bir kalkınma stratejisi tasarlama fikri bu koşullar altında doğmuştur. ${ }^{46}$

Temel ihtiyaçlar yaklaşımı sayesinde gelecekte gerçekleşmesi arzu edilen yıllık kişi başı gelir düzeyi saptamaya dayanan o zamana kadarki gelenekselleşmiş uygulama-

43 Needs Based Development (Yazar Yok), http://www.repository.up.ac.za/bitstream/ handle/2263/28771/03chapters7-10.pdf? sequence $=4$.

44 Taylor-Gooby, “Equality, Rights”, s.27.

45 Paul P. Streeten, “Basic Needs: Premises and Promises”, World Bank Reprint Series: Number Sixty-two, Journal of Policy Modeling 1, 1979, s.136.

46Desmond McNeill, "Multilateral Institutions: A Critical Overview”, Poverty, Politics and Development: Interdisciplinary Perspectives, Fagbokforlaget, Bergen, 2006, ss.275-279: Emmerij, “The Basic Needs”, s.1. 
lar tersine çevrilmiştir. Bu geleneksel uygulamalar daha çok gelecek hedeflerine dayanmaktayken, temel ihtiyaçlar yaklaşımı kesin üretim hedefleri saptayarak ve arzu edilen ekonomik büyüme oranlarına bu sayede ulaşarak çok daha fazla bir kesinlik elde etmiştir. Bu açıdan bakıldığında, temel ihtiyaçlar yaklaşımına dayalı kalkınma stratejisi, geleneksel stratejilerden çok daha uygulanabilir görünmektedir. ${ }^{47}$ Çünkü ihtiyaç temelli yaklaşım, yukarıdan aşağı doğru ilerleyen diğer yaklaşımları tersine çevirmiş ve asıl vurguyu sosyal koruma ihtiyacı içindeki yoksul kesimler üzerine yöneltmiştir. Sistematik bir bilgi toplama süreci sayesinde ihtiyaçların niteliği, şiddeti ve ne zamandır geçerli oldukları gibi konuların bir yere kadar saptanması mümkün olmuştur. Bu sürecin sonunda ise ihtiyaçlara ilişkin toplanan bilgiler ışığında müdahale politika ve programları belirlenmektedir. Söz konusu politika ve programların, doğrudan doğruya ihtiyaç analizi yapılarak tasarlandıkları için ihtiyaçların giderilmesi noktasında alternatif modellere kıyasla çok daha etkili olacağı ileri sürülmektedir. ${ }^{48}$ Ancak tüm bu teorik temellerine ve sağlamlığına rağmen, bu ilk dönem boyunca kalkınma tartışmalarında ana akım bir yaklaşım haline gelememiştir.

Uygulama açısından yeterince yaygınlaşamamasının nedenlerinden biri, temel ihtiyaçların tam olarak karşılanabilmesi için gereken yıllık ekonomik büyüme oranının, birçok ülke örneğinde de görüleceği üzere $\% 8$ gibi oldukça yüksek ve gerçekçi olmayan bir seviyede belirlenmiş olmasıdır. Doğu Asya ve daha sonrasında da Çin ve Hindistan sırasıyla bu oranları yakalamıştır. Ancak 1970’li yılların ortalarında Doğu Asya ve Çin mucizeleri artık geride kalmıştır. Dolayısıyla temel ihtiyaçları sadece çok yüksek ve gerçekçi olmayan ekonomik büyüme performansıyla karşılamaya dayalı bir politikanın uygulanamaz olduğu ve bunun yerine başka alternatif yaklaşımların gerektiği kesin olarak anlaşılmıştır. Bunun üzerine, temel ihtiyaçlar hedeflerine ulaşmak için ekonomik büyüme oranı ile gelir dağılımı politikalarının bir arada yürütülmesinin etkili olacağı ileri sürülmüştür. Yani, sonrasında bir bölüşüm ve dağıtım politikası uygulanmadığı takdirde temel ihtiyaçlar hedeflerine ulaşabilmenin ancak gerçekçi olmayan yıllık büyüme oranlarıyla mümkün olduğu, bu nedenle yakalanan çok daha mütevazı büyüme oranlarının, hemen sonrasında uygulanacak etkili bölüşüm politikalarıyla tamamlanması gerektiği savunulmuştur. Gerçekten de gelir dağılımı eşitsizliği azaltılırsa, yüksek ekonomik büyüme ihtiyacı da düşecektir. "Büyüme kaynaklı yeniden dağıtım” ile temel ihtiyaçlar hedeflerinin yıllık \%6 gibi çok daha gerçekçi bir büyüme ortalamasıyla sağlanabileceği çeşitli araştırmalarla saptanmiştır. ${ }^{49}$

Her ne kadar temel ihtiyaçlara dayalı sosyal kalkınma yaklaşımının ortaya çıkmasına ILO vesile olmuş olsa da bir başka etkili küresel aktör olan Dünya Bankası da yaklaşık olarak aynı dönemde temel ihtiyaçlar yaklaşımını bir bütün olarak destekleme kararı almış ve operasyonel birimlerini bu doğrultuda çalışmaya sevk etmiştir. Temel

47 Emmerij, "The Basic Needs”, s.1.

48 Needs Based Development (Yazar Yok), http://www.repository.up.ac.za/bitstream/ handle/2263/28771/03chapters7-10.pdf? sequence $=4$.

49 Emmerij, “The Basic Needs”, s.1. 
ihtiyaçlar bu süreçte genellikle iktisat kökenli olan hükümet plancıları tarafından kavramsallaştırılan ve özelleştirilen "temel maddi ihtiyaçlar” şeklinde yorumlanmıştır. 2000-2003 yılları arasında Dünya Bankasının baş ekonomisti ve kıdemli başkan yardımcılığı görevlerini de yürüten Nick Stern, 1980'li yıllarda kalkınma politikalarında ihtiyaçlar meselesine yönelik reddedici ve yok sayan genel tutumu şu şekilde özetlemiştir:

“Temel ihtiyaçlar fikri ya da daha yaygın ifadesiyle "temel ihtiyaçlar yaklaşımı", bazı ciddi sorunlar içermektedir. Hangi ihtiyaçlar temeldir, hangileri daha endişe uyandırıcıdır ve temel düzeyi somutlaştırmak için hangi düzeyler eşik kabul edilmelidir? Bu eşikler karşılanması mümkün olmayan eşikler olduğunda ne yapılacaktır? Hangi ihtiyaçların temel olduğuna ve hangi eşiğin doğru eşik olduğuna kimler karar verecektir? Bireyler karşılama yetenekleri ve güçleri olduğu halde, yine de söz konusu ihtiyaçlarını karşılamamayı tercih ettiklerinde, bu ihtiyaçların temel ihtiyaçlar olduğu nasıl ileri sürülebilir? Bu soruların cevaplanması kolay değildir ve bu da temel ihtiyaçlar yaklaşımının tutarlılığ 1 konusunda genel bir şüphenin oluşmasına yol açmaktadır". ${ }^{50}$

Ancak ilginç ve bir o kadar da ironik bir şekilde, Stern 1990'lı yılların sonunda bizzat kendisinin de vurguladığ mel ihtiyaçların karşılanması önceliğine dayanan bir program olan "Binyıl Kalkınma Hedeflerine" bağlılığını ilan etmiştir. Bu yeni hedefler ve politikalar paketiyle makul bir yaşam süresine sahip olma, kolayca kontrol altına alınabilir hastalıklara yakalanmama, okuryazarlık, fiziksel şiddete maruz kalmama gibi bazı ihtiyaçlar somut şekilde tanımlanmış ve somutlaştırılmıştır. ${ }^{51}$

Ancak temel ihtiyaçlar yaklaşımı zaman içinde yeniden gözden düşmüş ve önemini kaybetmiştir. Bunun esas olarak politik ekonomiden ve siyasi koşullardan kaynaklanan nedenleri olmakla birlikte, başka bazı faktörler de bunda etkili olmuştur. İlk olarak, yaklaşıma ilişkin farklı kaynaklar arasında bir netlik bulunmamakta ve bunlar çoğu zaman kendilerine özgü çıkarımları nedeniyle birbirleriyle çelişmektedir. İkinci olarak, yeteri düzeyde süzülmüş ve sistematikleştirilmiş teknik bir dilin bulunmaması da yeterince canlı, akılda kalır ve kullanışı ıir tartışma alanı oluşmamasına yol açmaktadır. Son olarak, yeterince esnek ve çekici bir siyasi dil de bulunmamaktadır. ${ }^{52}$

Tüm bu eksikliklerin haricinde, ekonomik büyüme oranları açısından "kayıp yıllar" olarak adlandırılan 1980'li yıllar, milyonlarca insan için ciddi kayıplara yol açmıştır. 1980'li yılların başında klasik "bırakınız yapsınlar” anlayışına geri dönülmesi, gelir dağılımına müdahaleci devlet anlayışına siyasi ve akademik olarak güçlü bir muhalefetin doğmasına yol açmıştır. Daha aktivist bir devleti öngören temel ihtiyaçlar yaklaşımını da içeren kalkınma stratejileri, piyasa mucizesinin ulusal büyüme ve varlık günlerini geri getireceği iddiasıyla artık önemini yitirmiştir. Yeni dönemde, ulusal düzeyde içinde devletlerin olmadığı ve uluslararası düzeyde de denge sağlayı-

50 Nicholas Stern, “The Economics of Development: A Survey, The Economic Journal. IC, 1989, s.645.

51 Gasper, "Conceptualising Human Needs", s.4.

52Paul Spicker, "Needs as Claims", Social Policy and Administration, vol 27 no 1, 1993, s.10. 
c1 güçlerin bulunmadığı küreselleşme anlayışına dayalı kalkınma modellerine geçiş yaşanmıştır. Bu yeni model "Washington Mutabakatı" olarak adlandırılmaktadır. ${ }^{53}$

Temel ihtiyaçlar yaklaşımı 1970'li yılların sonundan itibaren ve 1980'li yıllar boyunca karşı karşıya kaldığı tüm eleştirel saldırılardan ve karalamalardan sonra, yeniden canlanmış ve çok daha somut biçimler alabilmiştir. Bu somut biçimlerin başında İnsani Kalkınma Raporları gelmektedir. Bu yeniden canlanmanın en önemli nedenleri, ihtiyaçlara yönelik farklı teorileştirme çabaları arasında daha başarılı bir ayrıma gidilebilmesi, daha güçlü bir kavramsallaştırmanın yapılabilmiş olması ve diğer yakın alan ve fikirlerle daha tutarlı bir ilişkinin kurulabilmiş olmasıdır. ${ }^{54}$ Ancak tüm bu olumlu gelişmelere karşın, temel ihtiyaçlar yaklaşımı bu sefer de ne yazık ki yeterli bir makroekonomik ve sektörel çerçeveyle desteklenememiştir. Yine de sonuç itibariyle bakıldığında, 1980'li yıllardan sonra bir ilerleme yakalandığı kesindir. ${ }^{55}$

Zaman içinde teorinin güçlenmesiyle ve kavramsallaştırmanın gelişmesiyle, ihtiyaçlar yaklaşımı daha geniş bir entelektüel ve siyasal alana çok daha başarılı bir şekilde oturtulmuştur. Bu kapsamda "beşeri kalkınma" ve "beşeri güvence" gibi daha etkili ve daha isabetli başlıklandırmalar yapılmış ve sonrasında da insan hakları konusuyla daha güçlü ilişkiler kurulmuştur. Bu süreçte, İnsani Gelişim Endeksi başta olmak üzere, birçok dikkat çekici ve gündem yaratıcı endeksler de geliştirilmiştir. Yine aynı süreçte, Birleşmiş Milletlerin İnsani Gelişim Rapor Ofisi entelektüel, bağımsız ve etkili bir birim olarak kurulmuştur. ${ }^{56}$ Tüm bu kurumsal ve fikirsel gelişmeler, temel ihtiyaçlar alanının bağımsız bir çalışma alanı olmasını ve sosyal politika yazınında sağlam bir yer edinmesini kolaylaştırmıştır.

\section{İhtiyaç Temelli Yaklaşımın Eleştirisi}

İhtiyaç temelli yaklaşımın sosyal koruma ve sosyal kalkınma alanlarına yeni bir anlayış getirdiği kesindir. Ancak gerek teorik temellerinde gerek uygulama safhasında bazı önemli eksikleri bulunmaktadır. En fazla eleştirildiği konuların başında mevcut toplumsal düzeni topyekûn dönüştürecek sistematik değişimlere yol açma konusunda yetersiz kalması gelmektedir. Daha açık bir ifadeyle, yoksulları sürece dahil ettiği halde, sarsılmaz bir sosyal adalet getirecek politikaları ve yasal düzenlemeleri hayata geçirme konusunda başarısız kalmıştır. ${ }^{57}$

Aynı zamanda, toplumda kendinden önce var olan kutuplaşmaları ve geçerli algı düzenini kırmada da kayda değer bir başarı sağlayamamıştır. Nitekim yoksulların yeterince çabalamayan ve hazır yardımları bekleyen tembeller, varlıklı insanların ise potansiyel iyiliksever, hayırsever ve cömert bireyler oldukları şeklindeki geleneksel algıyı değiştirememiştir. Yani bireyler arası dayanışma ve yardımlaşma düzenini, yasal hak ve vatandaşlık temelli düzene çevirme konusunda etkili olamamıştır. Bunu

53 Emmerij, “The Basic Needs”, s.2.

54 Gasper, "Conceptualising Human Needs", s.5.

55 Stewart, “Human Development”, ss.12-15; Emmerij, “The Basic Needs”, s.2.

56 Gasper, “Conceptualising Human Needs”, s.6.

57 Introduction to the Rights Based Approach (Yazar Yok),

http://www.replace-campaign.org/resources/introduction-to-the-rights-based-approach.pdf, s.1. 
gerçekleştirmenin en etkili yollarından biri olan, siyasi yapılara ve diğer etkili karar alıcılara sistematik bir değişiklik için zorlamada bulunma konusunda da başarılı değildir. Dolayısıyla, hayırseverler önceden olduğu üzere yoksulların ihtiyaçlarını ancak kaynaklar müsait olduğunda ve ancak kendileri fark edip istekli olduklarında karşılamaya devam etmiştir. Ayrıca, kendi içinde de bazı tutarsız tarafları vardır. Bunun en net örneği, bir taraftan insanları toplumsal kalkınma süreçlerine dahil olmaya teşvik ederken, diğer taraftan daha üst düzey karar alma süreçlerinin dışında tutmaya çalışmasıdır. ${ }^{58} \mathrm{Bu}$ tutarsız durum, yaklaşıma karşı şüphelerin artmasına yol açmaktadır.

Öte yandan, ihtiyaç temelli yaklaşım özellikle birbiriyle çelişen ihtiyaçlar arasında nasıl bir seçim yapılacağı konusunda yetersizdir. Bu nedenle, bazı ihtiyaçların temel ihtiyaçlar olsalar bile karşılanamama ihtimalinin bulunduğu düşünülmektedir. Ayrıca insanları otonom, bağımsız ve yansıtıcı aktörler olarak görmek yerine, zaaf noktaları bulunan, birbirlerine karşılıklı bağımlı olan ve toplumsal ihtiyaçları bulunan karmaşık bir toplumun üyeleri olarak görmektedir. Çeşitli sosyal grupların bir-

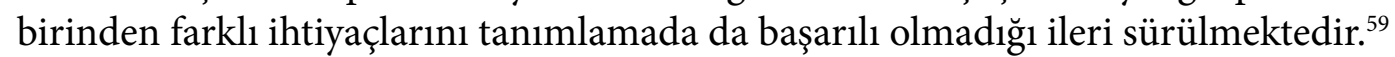

Tüm bu eleştirilere kıyasla çok daha yapısal bir eksiklik olarak, temel ihtiyaçlar yaklaşımının genellikle günlük tüketim ve refah harcamalarını arttırmak suretiyle, genel tasarruf eğiliminde ve verimli yatırımlarda bir azalmaya ve çalışma isteğinde bir gerilemeye yol açtığı iddia edilmektedir. Bunun da uzun vadede ekonomik büyüme performansları üzerinde mutlaka olumsuz etkilerinin olacağı savunulmaktadır. ${ }^{60}$ Ancak temel ihtiyaçlar yaklaşımıyla ekonomik büyüme kavramlarının doğrudan karşılaştırılabilir kavramlar olmadıklarının belirtilmesi gerekir. Çünkü büyüme üretim ve gelir düzeyindeki yıllık artışlara ve genel olarak geleceğe vurgu yapmaktadır. Temel ihtiyaçlar yaklaşımında da bir zaman boyutu vardır. Ancak temel ihtiyaçlar yaklaşımı gittikçe artan bir nüfusun dinamik ve değişken temel ihtiyaçlarını etkin biçimde karşılayacak politikaların geliştirilmesine vurgu yapmaktadır ve asıl olarak şimdiyle ilgilenmektedir.

Tüm bu eksikleri nedeniyle, temel ihtiyaç yaklaşımının başarılı bir sosyal koruma politikası olamayacağı ileri sürülmektedir. Hatta bir adım daha ileri gidip, ihtiyaç teriminin içerdiği belirsizlikler nedeniyle sosyal politika bağlamında hiç kullanılmaması gerektiği; bunun yerine risk, özellikle de yoğun risk kavramı başta olmak üzere başka terimlerin kullanılması gerektiği belirtilmektedir. Böylelikle, belirsizliğin azalacağı ve sorunların tespitinin, yoğunluklarının anlaşılmasının ve karşı tedbirler geliştirilmesinin kolaylaşacağı iddia edilmektedir. ${ }^{61}$

Bu öneri biraz aşırı gibi görünmekte ve ihtiyaç temelli yaklaşımın olumlu özelliklerini ve üstün taraflarını hiç dikkate almamaktadır. Bu nedenle, ihtiyaç temelli yaklaşımı tamamen reddederek güncel sosyal politika ve insani yardım tartışmalarından

58 Introduction to the Rights Based Approach (Yazar Yok),

http://www.replace-campaign.org/resources/introduction-to-the-rights-based-approach.pdf, s.2.

59 Taylor-Gooby, "Equality, Rights", s.28.

60 Streeten, "Basic Needs”, Taylor-Gooby, "Equality, Rights”, s.139.

61 Gasper, "Conceptualising Human Needs”, s.8. 
çıkarmak yerine, ihtiyaç dilini daha da geliştirmek ve sadeleştirmek daha isabetli bir alternatif olacaktır. Dolayısıyla bu kavramın bir miktar daha açıklığa kavuşturulmaya ve daha ileri analizlere ihtiyacı bulunduğu ortadadır.

\section{Sonuç}

Sosyal koruma güvencesine sahip olma hakkı kesinlikle en tartışmasız ve temel insan haklarından biridir. Bu hakkın güvence altına alınması günümüzde doğrudan doğruya devletin sorumluluğu altında kabul edilmektedir. Bu nedenle, tüm devletler bu en temel insan hakkını koşulsuz güvence altına almak üzere gerekli düzenlemeleri yapmak ve bunları sürekli güncellemek zorundadır. İhtiyaç temelli sosyal koruma yaklaşımı, böyle bir zorunluluğu yerine getirmeye yönelik geliştirilmiş alternatiflerden biridir.

Beşeri ve toplumsal ihtiyaç kavramının uzun bir geçmişi olmakla birlikte, bunun "temel ihtiyaçlar yaklaşımı" şeklinde sosyal koruma alanına aktarılması nispeten yeni bir durumdur. 1970’lerde önceleri ILO’nun, daha sonraları ise Dünya Bankası başta olmak üzere diğer önde gelen küresel örgütlerin öncülügünde geliştirilen bu yaklaşım, günümüze gelene kadar dalgalı bir seyir izlemiştir. Daha açık bir ifadeyle, bir on yıldan diğerine ya güç kazanmış ve küresel çapta yaygınlaşmış ya da tam tersine zayıflamış ve uygulama alanı daralmıştır. Bu dalgalanmada hem teorik arka plandaki eksiklerinin hem de son derece dinamik sosyoekonomik düzene karşı aynı dinamizmi gösterememesinin, kısacası uygulamadaki başarısızlıklarının etkisi olmuştur.

İhtiyaç kavramı doğası gereği soyut ve muğlak bir kavramdır. Bu nedenle, tanımlanması ve karşı tedbirler alınması kolay değildir. Nitekim içsel ve dışsal birçok etmenden etkilenmektedir. Dolayısıyla belli bir birey ya da birey grubu için tanımlanan bir temel ihtiyaçlar listesi bir başka birey ya da birey grubu için geçerli olmayabilir. Aynı toplum içinde yaşıyor olsalar bile bu durum değişmeyecektir. Benzer biçimde, birey için belli bir dönemde geçerli olan ihtiyaçlar zaman içinde geçerliliğini kolaylıkla yitirebilmektedir. Çünkü beşeri ve toplumsal ihtiyaçlar bireyin karakter yapısına, psikolojik durumuna, yaşına, cinsiyetine, sosyoekonomik statüsüne, gelir ve eğitim düzeyine, ülkenin genel sosyoekonomik yapısına ve gücüne, geleneklerine, kültürüne ve en önemlisi de hakim olan siyasi ideolojiye göre sürekli değişmektedir. Bu nedenle, her dönem ve herkes için geçerli tek bir ihtiyaç temelli yaklaşım tasarlamak, neredeyse imkansızdır.

$\mathrm{Bu}$ gerçekten hareketle, ihtiyaç teorisyenleri “temel ihtiyaçlar yaklaşımını” ortaya atmışlar ve ihtiyaçlardaki bu oynaklık ve değişkenlik karşısında tek çıkar yolun herkes için geçerli olacak en temel ve en asgari düzeylerin belirlenmesi ve buna göre bir sosyal koruma sisteminin oluşturulması önermesini geliştirmişlerdir. Sosyal politika ve sosyal koruma yazınına "temel ihtiyaçlar yaklaşımı" olarak geçen bu önermenin daha en başta karşılaştığı en ciddi meydan okuma, herkesi bağlayacak söz konusu asgari ya da temel düzeyin ne olduğunun tespit edilmesidir. Hatta bu düzeyin bizzat birey tarafından mı belirlenip talep edileceği, yoksa toplum ya da yönetenler tarafından mı tespit edilmesinin ve sağlanmasının daha doğru olduğu hala tartışılmakta 
olan bir sorudur. Meseleye insan hakkı ve özel yaşamın dokunulmazlığı temelinde, yani biraz daha sol bir pencereden bakanlarla, ekonomik gerçekler, yani sağ görüş penceresinden bakanlar bu soruya taban tabana zit yanitlar vermektedir. Dönemsel olarak hangi görüş ideolojik ve siyasal üstünlüğü elinde bulunduruyorsa, ihtiyaç temelli yaklaşımın uygulanma yaygınlığı ve gücü de ona göre şekillenmektedir.

Temel ihtiyaçlar yaklaşımının sosyal koruma alanına getirmeye çalıştığı asıl yenilik, ihtiyaçların doğasında bulunan soyutluğu ortadan kaldırıp, bunların yerine çok daha somut kavramlar kullanmaya çalışması ve araçlar yerine sonuçlara vurgu yapmasıdır. Bir başka yeni ve özgün özellik olarak, temel ihtiyaçlar yaklaşımı "maddi olmayan" ihtiyaçlara da ayrı bir vurgu yapmaktadır. Bu maddi olmayan ihtiyaçlar kendi kaderini tayin etme, kendine güvenme, siyasi özgürlük ve güvence, karar alım süreçlerine katılım, ulusal ve kültürel kimlik ve gündelik hayatta ve çalışma hayatında bir amaca sahip olma duygusudur. Bu maddi olmayan ihtiyaçların bazıları maddi ihtiyaçları karşılamanın da ön şartları olmakla birlikte, örneğin temel maddi ihtiyaçları karşılama ve özgürlüğün belli türleri gibi başka ihtiyaçlar zaman zaman birbiriyle çelişebilmektedir. Yani, belli ihtiyaçlar birbirleriyle hem çelişebilmekte hem de birbirini tamamlayabilmektedir. Bu iç içe geçmiş ve karmaşı yapı, temel ihtiyaçlar yaklaşımının tutarlı ve yüksek bir sosyal koruma performansı sergilemesinin önündeki en büyük engellerden biridir.

Sonuç olarak, temel ihtiyaçlar yaklaşımının kendi içinde bazı güçlü ve üstün yanları olmakla birlikte, örneğin yasal hak ve vatandaşlık temelli alternatif sosyal koruma yaklaşımıyla karşılaştıııldığında yetersiz kalmaktadır. Çünkü hak temelli yaklaşımın sunduğu dönemden döneme ve kişiden kişiye değişmeme ve tutarlı olma özelliklerini taşımamaktadır. Üstelik bir siyasi iktidardan diğerine kapsamı ve etki alanı değişme eğilimi de göstermektedir. Bu nedenle de bireylerin kesintisiz ve güvenceli sosyal korumaya sahip olmalarını garanti edememektedir.

\section{Kaynakça}

Abercrombie, Nicholas, Stephen Hill ve Bryan S. Turner, The Penguin Dictionary of Sociology, London, UK, Penguin Books, 1994.

Alcock, Cliff, Sarah Payne ve Michael Sullivan, Introducing Social Policy, Prentice Hall, UK, 2000.

Bannock, Graham, Ron Eric Baxter ve Evan Davis, The Penguin Dictionary of Economics 5th Edition, London, UK, Penguin Books, 1992.

Barusch, Amanda Smith, Foundations of Social Policy Social Justice in Human Perspective, the USA, Brooks/Cole, 2009.

Blakemore, Ken ve Edwin Griggs, Social Policy: An Introduction, McGraw-Hill Education, 2007.

Bradshaw, Jonathan, "A Taxonomy of Social Need", Problems and Progress in Medical Care, Edt: McLachlan G., Seventh Series NPHT/Open University Press, 1972.

Doyal, Len ve Ian Gough, A Theory of Human Needs, Basingstoke: Macmillan Education, 1991. 
Emmerij, Louis, “The Basic Needs Development Strategy”, Background Paper World Economic and Social Survey, 2010.

Gasper, Des, "Conceptualisng Human Needs and Wellbeing”, Wellbeing in Developing Countries: New Approaches and Research Strategies, Edt: I. Gough ve J.A. MacGregor, Cambridge University Press.

Honderich, Ted, The Oxford Companion to Philosophy, Oxford University Press, 2nd Edition.

Introduction to the Rights Based Approach (Yazar Yok), http://www.replacecampaign.org/resources/introduction-to-the-rights-based-approach.pdf.

Jackson, Tim, Wander Jager and Sigrid Stagl, "Beyond Insatiability: Needs Theory, Consumption and Sustainability", Consumption: Perspectives from Ecological Economics. Edt: Reisch, L. ve I. Røpke, Cheltenham: Edward Elgar, 2004.

Manning, Nick, "Social Needs, Social Problems, and Social Welfare and Well-being", The Student's Companion to Social Policy, Fourth Edition, Edt: Pete Alcock, Margaret May, Sharon Wright, John Wiley \& Sons, 2012.

McCaslin, N. L., ve Jovan P. Tibezinda, “Assessing Target Group Needs”, Improving Agricultural Extension: A Reference Manual, Edt: Swanson, B.E., R.P. Bentz, ve A.J. Sofranko, Food and Agriculture Organization of the United Nations, Rome, 1997.

McLean, Iain ve Alistair McMillan, The Concise Oxford Dictionary of Politics, Oxford University Press, 2nd Edition, 2003.

McNeill, Desmond, "Multilateral Institutions: A Critical Overview", Poverty, Politics and Development: Interdisciplinary Perspectives, Fagbokforlaget, Bergen, 2006, ss.275-279: Emmerij, “The Basic Needs”.

Nafziger, Wayne, "From Seers to Sen: The Meaning of Economic Development", UN University/World Institute for Development Economics Research (WIDER) Jubilee Conference, 17-18 June 2005.

Needs Based Development (Yazar Yok), http://www.repository.up.ac.za/bitstream/ handle/2263/28771/03chapters7-10.pdf? sequence $=4$.

Page, Robert M., “The Post-War Welfare State”, The Student's Companion to Social Policy, Fourth Edition, Edt: Pete Alcock, Margaret May, Sharon Wright, John Wiley \& Sons, 2012.

Plant, Raymond, "Socialism, Markets, and End States", Market Socialism, Oxford, 1989.

Reber, Arthur, The Penguin Dictionary of Psychology, London, UK, Penguin Books, 3rd Edition, 1994.

Seers, Dudley, “The Limitations of the Special Case", Bulletin of the Oxford Institute of Economics and Statistics, 25(2), 1963.

Seers, Dudley, “The Meaning of Development”,囚IDS Communication Series, No: 44, 1969.

Sen, Amartya, Development as Freedom, Alfred A. Knopf, New York, 1999.

Shue, Henry, Basic Rights, Subsistence, Affluence, and U.S. Foreign Policy, Second Edition, Princeton University Press, USA, 1996. 
Stewart, Frances, "Human Development as an Alternative Development Paradigm", http://hdr.undp.org/docs/training/oxford/presentations/2004/topic_1.

Streeten, Paul P., "Basic Needs: Premises and Promises", World Bank Reprint Series: Number Sixty-two, Journal of Policy Modeling 1, 1979.

Taylor-Gooby, Peter, "Equality, Rights, and Social Justice", The Student's Companion to Social Policy, Fourth Edition, Edt: Pete Alcock, Margaret May, Sharon Wright, John Wiley \& Sons, 2012.

Wetherly, Paul, "Basic Needs and Social Policies", Critical Social Policy, SAGE London, Thousand Oaks, CA and New Delhi, Vol. 16, 1996. 


\title{
Social Protection on the Base of "Needs": Basic Needs Approach
}

\author{
DOĞA BAŞAR SARIIIPEK
}

\begin{abstract}
Needs are not easy to define. In this sense, the questions of which criteria are applied to determine needs, what the basic and further needs are, how the ones who are in need are distinguished from the others etc. are constantly asked while designing policies of social welfare and protection. Needs based approach is a social protection mechanism which was introduced as a response for these questions. Yet, it is not an easy measure to take due to the subjective features and uncertainties in the very nature of the concept of need itself. Therefore, a conceptual restriction, in the form of "basic needs", was applied in practice. The purpose of basic needs approach is the provision of the required opportunities in order to reach a full-development of individuals and allocate certain resources for certain groups in conformity with this purpose. The core of basic needs approach is to fill in the gap between actual living standards and needs in such a shorter time and the least resources as much as possible in comparison with other alternative approaches. This approach, however, seems far beyond the rights-based approach in the performance of the provision of social protection due to the major shortcomings stemming from the theory itself.
\end{abstract}

Keywords: Needs, Basic needs, Social protection, Social policy, Welfare. 